\title{
Marococandona, a new genus of Candonidae (Crustacea, Ostracoda) from Southern Morocco : morphological characteristics and ecological requirements
}

\author{
P. Marmonier ${ }^{*}$, M. Boulal ${ }^{2}$, B. Idbennacer ${ }^{3}$ \\ ${ }^{1}$ Université de Rennes I, UMR- CNRS nº553, Campus de Beaulieu, Bat. 14A, 263 Av. Général Leclerc, 35042 Rennes Cedex, France. \\ ${ }^{2}$ Lycée Mohamed Reda Slaoui et centre des CPGE-AGADIR, Inezgane (Agadir), Morocco. \\ 369 Souk Dahmam,Guelmim, Morocco
}

\begin{abstract}
A new genus of hypogean Ostracoda, Marococandona nov. gen. from wells and springs in the Guelmin and Agadir regions (Southern Morocco) is described. This genus is close to the genus Candonopsis, but can be distinguished from this latter by several characteristics : the rectangular shape of the carapace, the reduction of the antenna chaetotaxy, the lack of sexual dimorphism in the male antenna, the lack of setae on the protopodite of the second thoracopod, and on the two first articles of the third thoracopod endopodite. M. danielopoli $\mathrm{n}$. sp. has primitive characters, with a normally segmented antennula, a ' $t$ ' seta on the anten$\mathrm{na}$, and normally developed furcal claws. In contrast, the morphology of M. nicolae $\mathrm{n}$. sp. is regressed, with a 5 segmented antennula, no 't' setae on the antenna, and a reduced furca. The two species live in highly mineralised water and seem poorly sensitive to groundwater pollution.
\end{abstract}

Keywords : Stygofauna, Candonopsis, adaptation, heterochrony, groundwater, new genus, new species.

\section{Introduction}

Despite that most zoological groups have colonized groundwaters, the biodiversity of stygofauna is generally considered as weaker than diversity of surface water organisms (Marmonier et al. 1993). This is not always true, the Crustacea Amphipoda, for example, can reach high species richness at both local and regional scales (Ginet 1982, Danielopol et al. 1999) and microcrustacea can reach similar diversity in both surface and groundwater at microscale (Rouch \& Danielopol 1997, Danielopol et al. 2002). For groundwater Ostracoda, one family (the Candonidae) is highly diversified and have colonized underground systems in most part of the world (e.g. West Indies, Broodbakker 1983, India, Gupta 1984, Africa, Martens 1992, Karanovic 2001, Australia, Karanovic 2003, Karanovic \&

\footnotetext{
* Corresponding author :

E-mail: pierre.marmonier@univ-rennes1.fr
}

Marmonier 2002, 2003). In the Mediterranean region, the stygobite Candonidae were mostly studied on the European side of the Mediterranean Sea : Spain (Paris 1920), Southern France (Danielopol 1977/78, 1978a), Italy (Klie 1938, Danielopol 1981b, Karanovic \& Pesce 2000), Slovenia (Klie 1931, 1935, 1940, Danielopol 1982, Griffiths \& Brancelj, 1996), Croatia (Rogulj \& Danielopol 1993), Montenegro (Karanovic 1999a, 1999b, 2000), Macedonia (Klie 1931), and Greece (Schäfer 1945, Danielopol 1981a). In contrast, the stygofauna of North Africa was poorly studied until a recent period (see Boutin \& Idbennacer 1989) and the hypogean ostracods of this region are totally unknown.

This gap in the knowledge of the stygofauna of North Africa is not only a problem for biogeographical and evolutionary reconstructions, but also a problem for groundwater management (Facker El Abiari 1999, Pospisil \& Danielopol 2000). The first step for the use of fauna as biological indicator is to describe the species potentially present at the regional scale (Notenboom et al. 1994) and to document their ecological re- 
quirements (Claret et al. 1999). This description gives to scientists the potential biodiversity of the region, the stock that can supply species to a specific ecosystem at a specific period, when environmental characteristics are appropriate for the development of this organism (Margalef 1997).

During two surveys of the Southern Moroccan ground waters, two new hypogean Candonidae (assigned by us to a new genus, Marococandona nov. gen.) were discovered. The topics of this paper are (1) to describe these two new species, (2) to discuss their morphological characteristics in the context of the adaptation to groundwater environment, and (3) to highlight their ecological requirements.

\section{Study site, material \& methods}

Marococandona danielopoli $\mathrm{n}$. sp. was sampled in the Guelmim area, in the Moroccan Anti-Atlas. The climate is arid with warm winters (Ionesco 1965). The study site pertain to the Seyad-Noum catchment area. This area is composed by numerous depressions in the Anti-Atlas and the Bani tableland, with an Infracambrian to Ordovician substratum. In the plain and valley, the substratum is formed by Acadian schist and covered by quaternary deposits. $M$. danielopoli $\mathrm{n}$. sp. was collected in a well (noted P38 in Boutin \& Idbennacer 1989) and a spring (Sa) located at South and West of Guelmim respectively. The aquifer of the well P38 is located in lacustrine marly sediments (Bouçenna 1985). The spring Sa is fed by interstitial water located in marly-calcareous and gypsum-rich sandy layers (Dijon 1966).

M. nicolae n. sp. was sampled in 17 different wells located near Agadir in the western part of the Souss valley, on the right side of the Oued Souss (noted 2, 3, $4,5,15$, and 16 in Boulal et al. 1997) and near the Oued Massa, $40 \mathrm{~km}$ South of Agadir. The studied area consists in a large costal plain (i.e. $80 \mathrm{~km}$ from North to South and $100 \mathrm{~km}$ from the Atlantic Ocean to the Atlas Mountains) located between Haut-Atlas and Anti-Atlas Mountains. The climate is arid with warm winters. The Souss plain is made of Plio-Quaternay fluvio-glacial deposits above a Tertiary substratum (marine Eocene). Groundwater quality strongly varied between wells and will be discussed later.

The wells were sampled using Cvetkov's phreatobiological net sampler (Cvetkov 1968, Bou 1974, Boutin \& Boulanouar 1983), a $50 \mu \mathrm{m}$ mesh-net. Two methods were used in the springs : drift filtration, through a $300 \mu \mathrm{m}$ mesh net, and artificial substrates composed of a ball of string enclosed in a metal grating box (Bournaud et al. 1978, Chauvin 1986, Vervier 1990). Animals were preserved in 5\% formaldehyde and in $70 \%$ alcohol after sample processing. Methods used for chemical characteristics of groundwater are presented in Boulal et al. (1997).

Specimens were dissected under stereo-microscope in glycerine. The limb description follows the model proposed by Broodbakker \& Danielopol (1982), modified by Martens (1987) for the male antenna and by Meisch (2000) for the second and third thoracopods. Abbreviations used for appendage coding are : Antennula : I to VIII endopodial segments, $\alpha$ short seta of the $7^{\text {th }}$ segment, $y_{\mathrm{a}}$ asthetasc of the $8^{\text {th }}$ segment ; Antenna : Pr protopodite, Exo exopodite, EI to EIV endopodial segments, $\mathrm{Y}$ asthetasc of EI, $\mathrm{y}_{1}, \mathrm{y}_{2}, \mathrm{y}_{3}$ asthetascs of EII+III and EIV, $\mathrm{t}_{1}-\mathrm{t}_{4}$ setae of EII, $\mathrm{z}_{1}-\mathrm{z}_{2}$ setae of EIII, $\mathrm{G}_{1}-\mathrm{G}_{3}$ claws of EII+III, Gm-GM claws of EIV ; Madibular palp : I to IV palp segments, $\alpha$ short seta of I, $\beta$ short seta of II, $\gamma$ seta of III ; Maxillular palp : I and II segments ; Maxilla (first thoracopod) : Pr protopodite, Mastic mastication part, Exo exopodite, a and d setae of the protopodite; Walking leg (second thoracopod) : Pr protopodite, EI to EIV endopodial segments, e seta of EI, f seta of EII, $g$ seta of EIII, $h_{1}$ and $h_{3}$ setae of EIV, $h_{2}$ claw of EIV ; Cleaning leg (third thoracopod) : Pr protopodite, EI to EIV endopodial segments, $\mathrm{d}_{1}$ and dp setae of the protopodite, g seta of EIII, $h_{1}$ to $h_{3}$ setae of EIV ; Furca (uropod in Meisch 2000) : $S_{a}$ and $S_{p}$ anterior and posterior setae, $\mathrm{G}_{\mathrm{a}}$ and $\mathrm{G}_{\mathrm{p}}$ anterior and posterior claws ; Hemipenis : a outer lobe, b inner lobe, $h$ mediale lobe, $d_{1}$ to $d_{3}$ sclerotized parts of the labyrinth, e bursa copulatrix, $\mathrm{M}$ internal process.

\section{Taxonomic description}

$\begin{array}{ll}\text { Class } & \text { Ostracoda Latreille, 1806 } \\ \text { Subclass } & \text { Podocopa G. W. Müller, 1894 } \\ \text { Order } & \text { Podocopida Sars, 1866 } \\ \text { Suborder } & \text { Podocopina Sars, 1866 } \\ \text { Infraorder } & \text { Cypridocopina Jones, 1901 } \\ \text { Superfamily } & \text { Cypridoidea Baird, 1845 } \\ \text { Family } & \text { Candonidae Kaufmann, 1900 } \\ \text { Subfamily } & \text { Candoninae Kaufmann, 1900 } \\ \text { Tribe } & \text { Candonopsini Karanovic, 2004 }\end{array}$

\section{Genus Marococandona n. gen.}

Carapace rectangular in lateral view, compressed in dorsal view, left valve overlapping the right one, no significant sexual dimorphism except size. Antennula (A1) with reduced chaetotaxy (lack of seta on the $3^{\text {rd }}$ 
article) and number of article in some species ( $3^{\text {rd }}$ article fused with the $4^{\text {th }}$ ). Antenna (A2) with elongated $\mathrm{Y}$ aesthetasc, penultimate segments fused without male bristles, number of ' $t$ ' setae reduced to one or zero. Second segment of the mandibular palp with $3+2$ setae, the two terminal segments conspicuously elongated. First thoracopod (Maxilliped) with only one 'a' seta and a respiratory plate with 2-3 filaments. Basal segment (protopodite) of the second thoracopod without seta. Basal segment of the third thoracopod with two setae, endopodial segments 1 and 2 without seta, one short and two long setae on the terminal segment. Furca without posterior seta, in some species furca reduced to a ramus and a single claw. Male Mxp-clasping organs weakly sclerotized, strongly asymmetric,
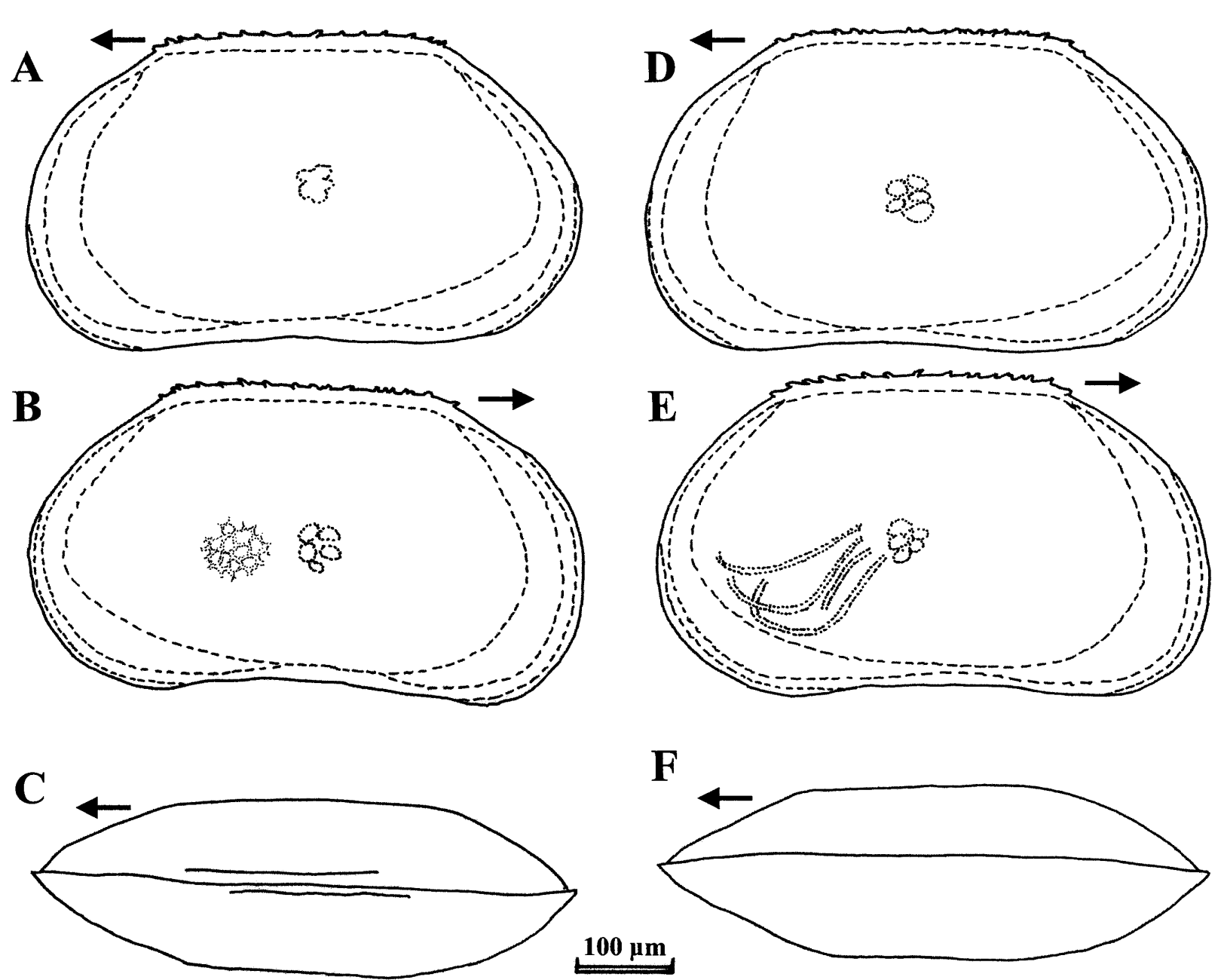

flat, d3-branch of the labyrinth surrounded by a sclerotized ovoid structure, d4-branch missing, outer lobe (a) elongated, roundly pointed, with a distal orientation. Zenker organ with $5+2$ chitinous rings.

Marococandona danielopoli n. sp. (Figs. 1, 2, 3)

Type material. Material deposited in the ostracod collection of the Royal Belgian Institute of Natural Sciences (Brussels, Belgium). Holotype, one dissected adult male (O.C. 2893) ; allotype, one dissected female (O.C. 2894). Paratypes : one male and one female dissected (O.C. 2895 - 2896), one male and one female not dissected (O.C. 2897 - 2898), a total of 32 individuals preserved in alcohol were observed.

$\mathbf{F}$

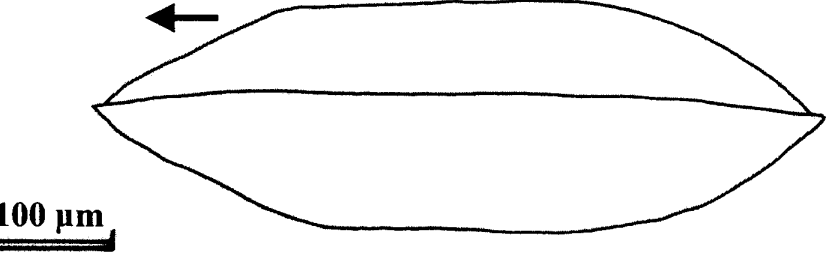

Fig. 1. Marococandona danielopoli $\mathrm{n}$. sp. female left valve (external view A), right valve (external view B) and complete animal (dorsal view $\mathrm{C}$ ), and male left valve (external view D), right valve (external view E) and complete animal (dorsal view F). 
Derivation of the name : this species is named after Dr Dan Danielopol (Mondsee, Austria), in honour of his contribution to the groundwater ecology and the systematics of ostracods.

Carapace. Small whitish animal, male $550 \mu \mathrm{m}$ long, $310 \mu \mathrm{m}$ height $(\mathrm{l} / \mathrm{h}=58 \%), 170 \mu \mathrm{m}$ width $(\mathrm{w} / \mathrm{l}=31 \%)$; female $550 \mu \mathrm{m}$ long, $300 \mu \mathrm{m}$ height $(1 / \mathrm{h}=54 \%)$, $170 \mu \mathrm{m}$ width. Rectangular shape of the carapace (Fig. 1) with symmetrical valves, the left valve overlaps the right one on dorsal, anterior and posterior margins. In lateral view (Figs. 1A, B, D \& E), the dorsal margin is straight, parallel to the ventral margin and bears several small teeth ; the cardinal angles are rough; posterior and anterior margins are regularly arched, ventral margin is slightly concave. In dorsal view (Figs. $1 \mathrm{C} \& \mathrm{~F}$ ), the carapace is flatted, the two lateral sides are parallel, posterior and anterior tips are pointed. The surface of the carapace is reticulated, particularly in the central part, near the muscle scars. The left valve (Figs. 1A \& D) is higher than the right, the hinge is straight with a simple sulcus. Vestibules represent both $10.5 \%$ of the total length, the anterior one is more developed on the ventral margin. The fused zone is large, it represents $25 \%$ of the vestibule width. The selvage is reduced but still visible on the posterior and anterior margins. Pore canals are simple and more numerous on the anterior margin. The right valve (Figs. $1 \mathrm{~B} \& \mathrm{E}$ ) has the same shape (but slightly reduced in size) with a more developed selvage. Males and females have very similar shape, the male is slightly higher. Eye not visible on the available material.

Antennula (Figs. 2B \& 3A). I+II : A-2l(pl), P21(pl)/ III : A-1m/ VI no seta / V : A-11, P-1s/ VI: A-21, P-1s/ VII : A-2l-1s $(\alpha)$, P-2s/ VIII : D-31-y ${ }_{a}$. The $y_{a}$ asthetasc is long, it represents 3.2 to 3.5 times the third endopodial segment length.

Antenna (Figs. 2A, 3D). Pr : P-1s/ Exo : 11-2s/

Male : EI : P-Y-11(pl)-1s/ EII+III: A-1s,P-y $-1 \mathrm{~m}\left(\mathrm{t}_{1}\right)$, D-2s $\left(\mathrm{z}_{1}, \mathrm{z}_{2}\right)-1 \mathrm{~s}\left(\mathrm{G}_{3}\right)-\mathrm{y}_{2}-1 \mathrm{~m}\left(\mathrm{G}_{1}\right)-11\left(\mathrm{G}_{2}: \mathrm{ser}\right) / \mathrm{EIV}: \mathrm{D}-$ $\mathrm{y}_{3}-1 \mathrm{~m}-1 \mathrm{~m}(\mathrm{Gm})-11(\mathrm{GM}: \mathrm{ser})$.

Female : EI : P-Y-11(pl)-1s/EII+III : A-1s, P-y $1 \mathrm{~m}\left(\mathrm{t}_{1}\right), \mathrm{D}-2 \mathrm{~s}\left(\mathrm{z}_{1}, \mathrm{z}_{2}\right)-1 \mathrm{~m}\left(\mathrm{G}_{2}\right)-2 \mathrm{l}\left(\mathrm{G}_{1}, \mathrm{G}_{3}: \mathrm{ser}\right) / \mathrm{EIV}: \mathrm{D}-$ $\mathrm{y}_{3}-2 \mathrm{~m}-2 \mathrm{l}(\mathrm{Gm}, \mathrm{GM}: \mathrm{ser})$.

The $\mathrm{Y}$ and $\mathrm{y} 3$ asthetascs are long, they represent respectively $163-187 \%$ and $76-110 \%$ of the anterior margin length of the first endopodial segment; their sensitive hyaline part are well developed, they represent 65 $68 \%$ (for Y) and 38-49\% (for y3) of their total length. Chaetotaxy reduced, the adults of both sexes have only two «Z» setae and only one «t» seta. The sexual di- morphism of the antenna is reduced : the second and the third endopodial segments are fused in both female and male (the latter has no transformed «t $2 »$ and «t3» bristles). Only claws show sexual dimorphism : compared to the length of the first endopodial segment, G1 represents $63 \%$ in male and $152 \%$ in female; G2 represents $161 \%$ in male and 59\% in female; G3 represents $22 \%$ in male (reduced to a simple seta) and $142 \%$ in female.

Mandibular palp (Fig. 3G). I : In-3m(pl)-1s( $\alpha$ )/ II : In-1s $(\beta: \mathrm{pl})-1 \mathrm{~s}(\mathrm{pl})-31(\mathrm{pl})$, Ex-2s/ III : In-2s-1m, Ex-2s $(\gamma)-1 \mathrm{~m} / \mathrm{IV}: \mathrm{D}-3 \mathrm{~s}-1 \mathrm{~m}(\mathrm{pl})$. The mandibular palp is elongated, the length of the third segment is 2.5 its width, the distal claw represents $120 \%$ the length of this third segment. The $\alpha$ and $\delta$ setae are smooth, $\beta$ seta is feathery. Maxillular palp (Fig. 3C). I : Ex-3l(pl)$1 \mathrm{~m}(\mathrm{pl}) / \mathrm{II}: \mathrm{D}-2 \mathrm{l}(\mathrm{pl})-2 \mathrm{~m}(\mathrm{pl})-2 \mathrm{~s}(\mathrm{pl})$. Maxilla or first thoracopod (Figs. 2E, 2F, \& 3H). Pr : A-1s(a), In1s(d)/ Mastic : D- 12s/ Exo : 2s-1m(pl)/ E : D-2s-1m. Respiratory plate with three filaments. The male prehensile organs have a sub-triangular section. The right one is long, with an external margin widely rounded, the left one is stocky and short, with a straight external margin. Both palps have thin and long distal tips.

Second thoracopod (Fig. 3E). Pr : no seta/ EI : A1s(e : pl)/ EII : A-1s(f : pl)/ EIII : A-1s(g:pl)/ EIV : D$2 \mathrm{~s}\left(\mathrm{~h}_{1}, \mathrm{~h}_{3}\right)-11\left(\mathrm{~h}_{2} \mathrm{G}: \mathrm{ser}\right)$. Protopodite without seta, third segment with only one setae, distal claw represents 1,7 time the first endopodial segment length. Third thoracopod (Fig. 3B). Pr : Ex-11(d $\left.\mathrm{d}_{1}: \mathrm{pl}\right), \mathrm{In}-1 \mathrm{~m}(\mathrm{dp}: \mathrm{pl}) /$ EI : no seta/ EII : no seta/ EIII : P-1s (g:pl)/ EIV : D$1 \mathrm{~m}\left(\mathrm{~h}_{1}: \mathrm{pl}\right)-2 \mathrm{l}\left(\mathrm{h}_{2}, \mathrm{~h}_{3}: \mathrm{pl}\right)$. The protopodite with 2 setae, the first and second endopodial segments without seta (e and $\mathrm{f}$ setae), the fourth segment setae represent respectively $57 \%, 105 \%$ and $112 \%$ of the first endopodial segment length. Furca (Figs. 2D \& 3F). No posterior seta, anterior seta short (14\% of the furcal anterior margin length), anterior claw long (82-92\% of the furcal anterior margin length) and weakly rounded, posterior claw short (51-59\% of the furcal anterior margin length) and strongly rounded. These two claws bear two rows of fine teeth. The furcal ramus is straight, slightly thinner in its central part than in its basal and distal ends. The furcal attachment has a strongly rounded dorsal branch, its ventral branch is divided in two perpendicular branch.

Genital organs. Female genital lobes (Fig. 3F) are widely rounded. The four studied females have only two big eggs ( $15 \%$ of the animal length). The hemipenis (Fig. 2C) has a pointed outer «a» lobe located on the distal side of the hemipenis; the «h» lobe is double rounded and bears a sclerotized internal ridge ; the $« \mathrm{~b} »$ 
A
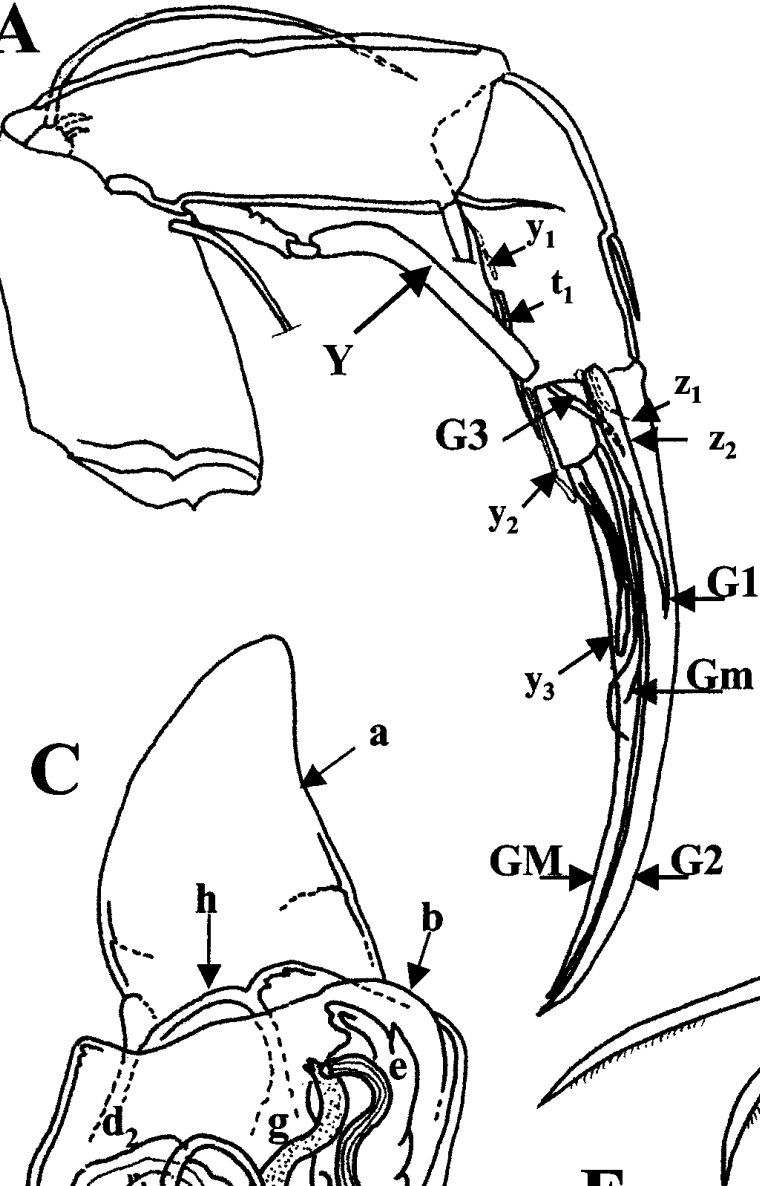

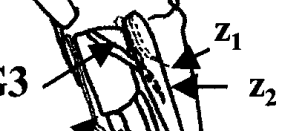

$\mathrm{y}_{2}$

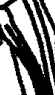

B

B

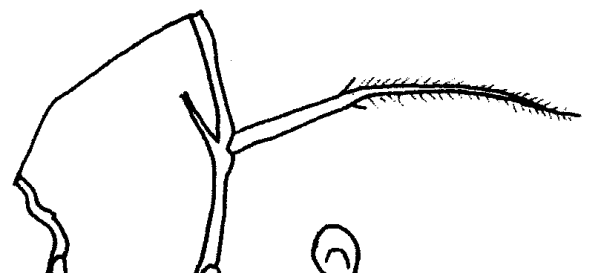

min<smiles>C=C</smiles>

$\mathbf{E}$

di 1 ind

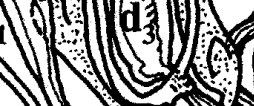

114

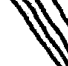

(3)

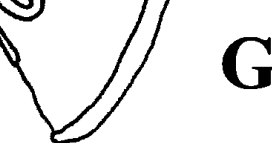

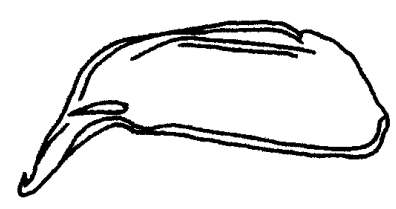

G

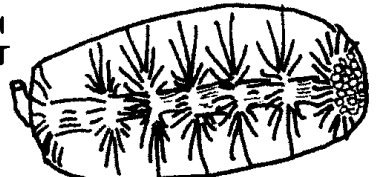

$\mathbf{F}$

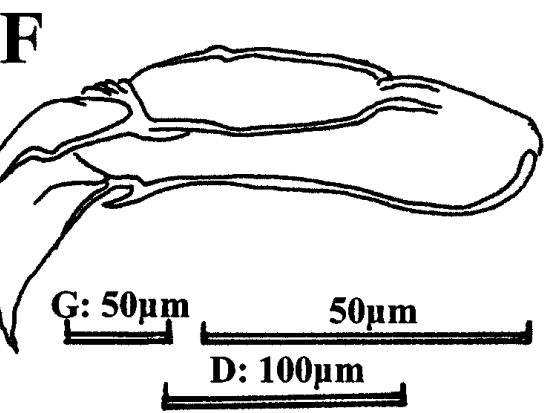

Fig. 2. Marococandona danielopoli n. sp. (male) antenna (A), antennula (B), hemipenis (internal view, C), furca and furcal attachment (D), left clasping organ $(\mathrm{E})$, right clasping organ $(\mathrm{F})$, zenker organ $(\mathrm{G})$, explanation in the text. 


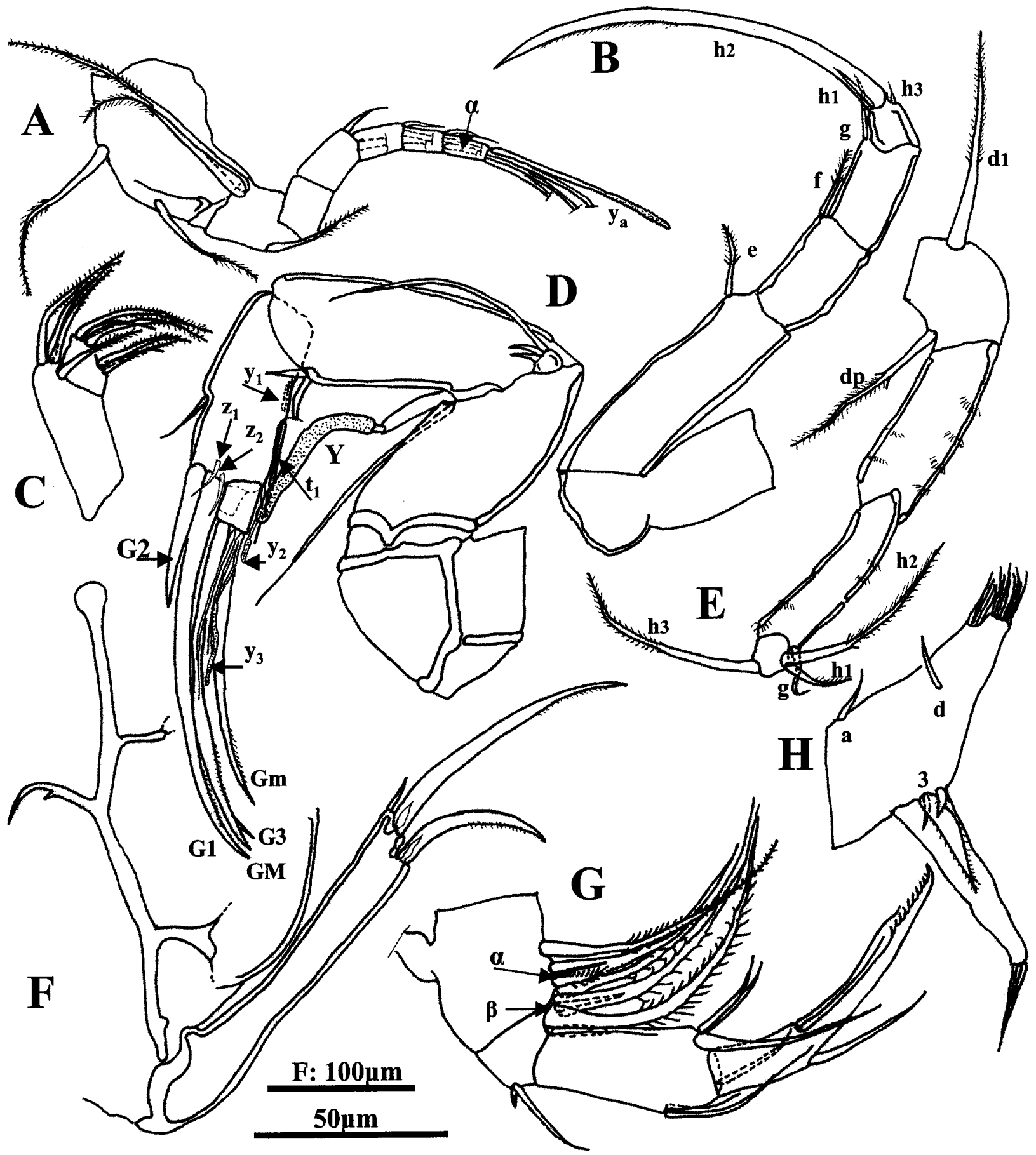

Fig. 3. Marococandona danielopoli n. sp. (female) antennula (A), second thoracopod (B), maxillular palp (C), antenna (D), third thoracopod (E), furca and furcal attachment $(\mathrm{F})$, mandibular palp $(\mathrm{G})$, maxilla $(\mathrm{H})$. 
lobe is low. The labyrinth is weakly sclerified, composed of three parts ( $\mathrm{d} 1, \mathrm{~d} 2$ et $\mathrm{d} 3$ ), $\mathrm{d}^{3}$ is well developed and surrounded by a sclerotized ovoid structure. The bursa copulatrix (e) is hook-shaped, the M-process is weakly sclerotized, S-shaped. Zenker organ (Fig. 2G) with $5+2$ chitinous rings. Testes have four lobes.

Marococandona nicolae n. sp. (Figs. 4, 5, 6, 7, 8)

Type material. Material deposited in the Ostracod collection of the Royal Belgian Institute of Natural Sciences (Brussels, Belgium). Holotype, one dissected adult male (O.C. 2899) ; allotype, one dissected female (O.C. 2900) ; paratypes, one dissected male (O.C. 2901) one dissected female (O.C. 2902), one male and one female not dissected (O.C. 2903 - 2904).

Derivation name : this species is named after Dr Nicole Coineau (CNRS Banyuls-sur-Mer), in honour of her contribution to the systematics of Crustacea and
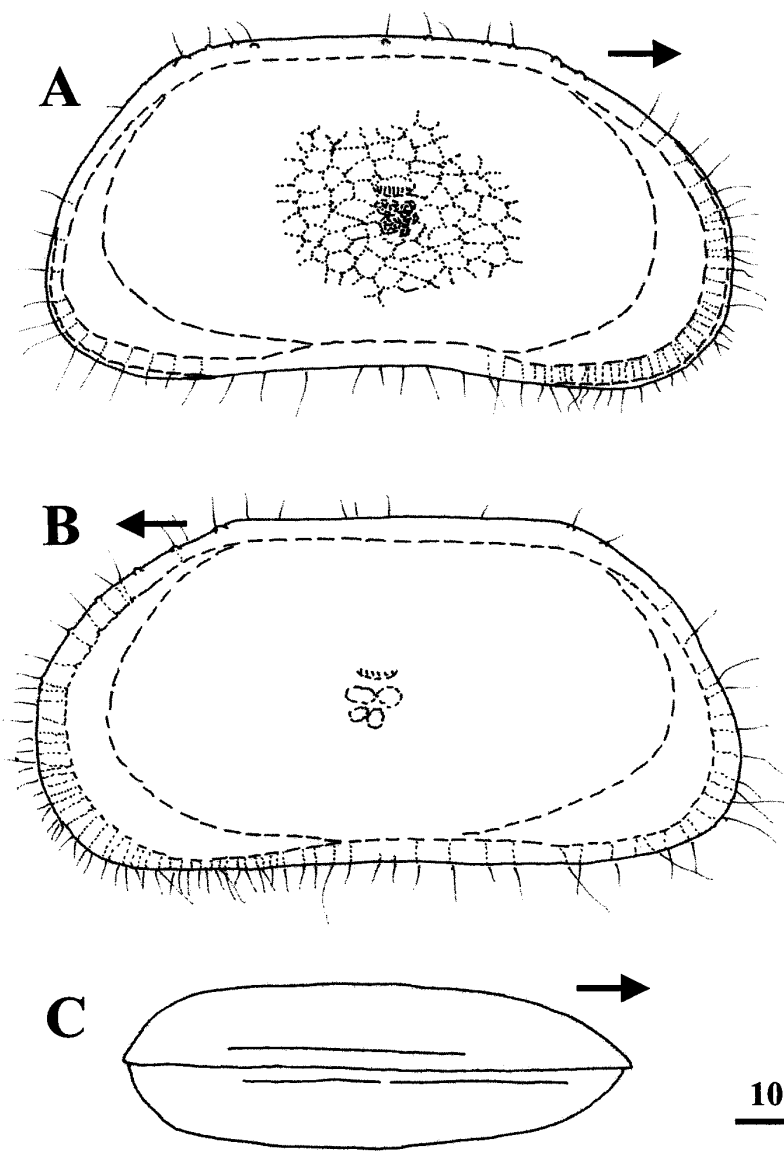

$100 \mu \mathrm{m}$

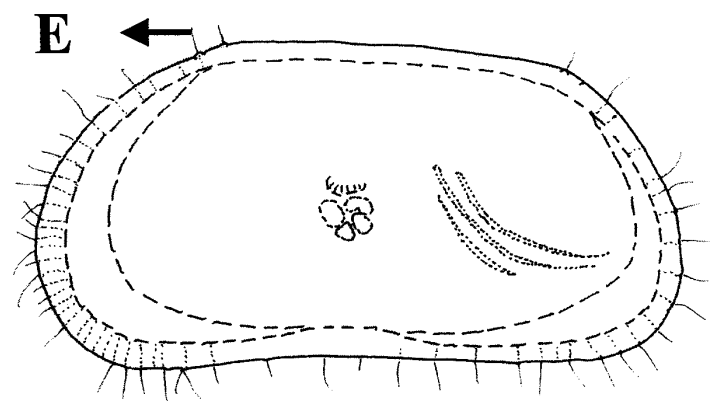

$\mathbf{F}$

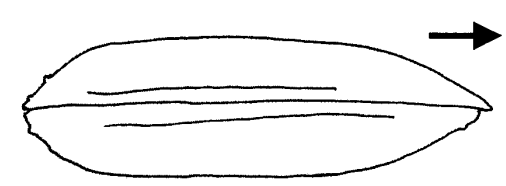

Fig. 4. Marococandona nicolae n. sp. female left valve (external view A), right valve (external view B) and complete animal (see from the top C), and male left valve (external view D), right valve (external view E) and complete animal (see from the top F). 

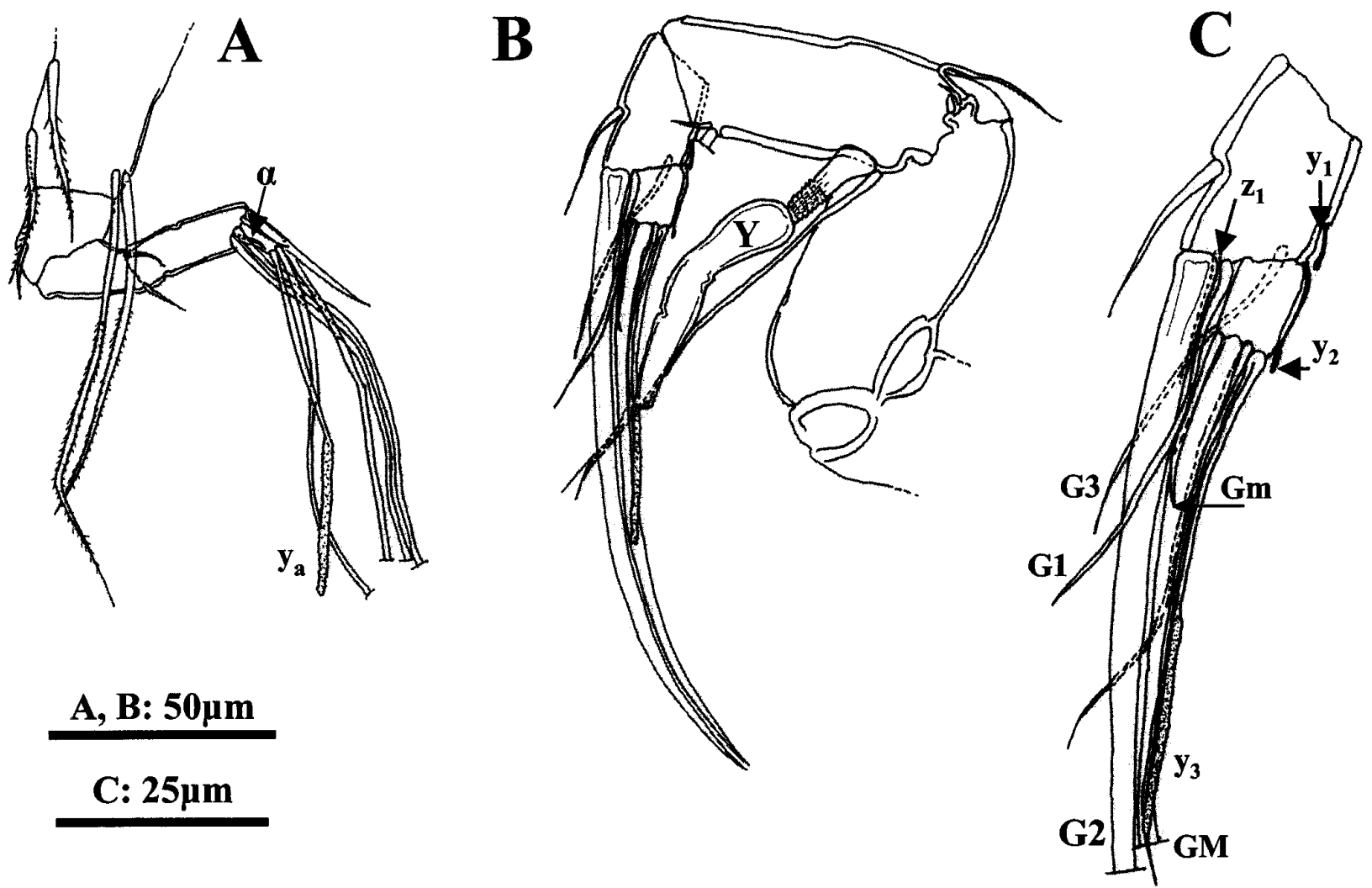

Fig. 5. Marococandona nicolae n. sp. (male) antennula (A), antenna (B, with detail of the distal part, C).

males). Anterior vestibule is regularly arched. For the male, it represents $9 \%$ of length on right valve and only $8 \%$ on left valve. For the female, it represents $8 \%$ and $7 \%$ of right and left valves respectively. Posterior vestibule is slightly larger ventrally than dorsally; it is smaller than anterior one in males, but equal or slightly larger in females. Marginal pore canals are normal and more numerous on the anterior margin than on the posterior one. In dorsal view (Figs. 4C and 4F), sides of animals look parallel with greatest widths located at the middle of the animal. Eye not visible on the available material.

Antennula (Figs. 5A \& 7A). I+II : A - 21 (pu), P $2 \mathrm{~m}(\mathrm{pu}) / \mathrm{III}: \mathrm{A}-1 \mathrm{~m} / \mathrm{IV}+\mathrm{V}: \mathrm{A}-1 \mathrm{~s}, \mathrm{P}-1 \mathrm{~s} / \mathrm{VI}+\mathrm{VII}$ : A - 1s, P - 21 - 1s $(\alpha) /$ VIII : D -1l (Gr) - $21-y_{a}$. Antennula made of 5 article, $3^{\text {rd }}$ and $4^{\text {th }}$, and $5^{\text {th }}$ and $6^{\text {th }}$ articles are fused. Sixth article bears 2 extremely long, one normal and one short $(\alpha)$ setae. The aesthetasc $y_{a}$ is very long, it represents $645 \%$ (in female) to $800 \%$ (in male) of the $7^{\text {th }}$ article length ; hyaline distal part well developed, it represents 42 to $45 \%$ of the total length of this aesthetasc.
Antenna (Figs. 5B, 5C, 7B, \& 7C). Pr : P - 11/ Exo : $2 \mathrm{~s}-1 \mathrm{~m} / \mathrm{EI}: \mathrm{P}-\mathrm{Y}-11$ (pu) - 1s.

Female : EII + III : A - 1s , P - $\mathrm{y}_{1}, \mathrm{D}-\mathrm{y}_{2}-2 \mathrm{~s}\left(\mathrm{z}_{1},{ }_{2}\right)$ - $1 \mathrm{~m}$ (G2 : ser) - 21 (G1, G3 : ser) / EIV : D - y $-21-11$ (Gm : ser ?) - 11 (GM : ser).

Second and third endopodial articles fused, Y aesthetasc represents 117 to $122 \%$ of EI length. Complete lack of internal ' $t$ ' bristles, only two external ' $z$ ' bristles ; G1 and G3 claws well developed (208\% and $197 \%$ of EI length); G2 claw reduced (70\% of EI length). The aesthetasc $y_{3}$ is very long (117\% of EI length) ; Gm and GM claws represent respectively $103 \%$ and $179 \%$ of EI length ; Gm claw is slightly shorter than aesthetasc $y_{3}$. Two long setae on EIV, one associated to $\mathrm{y}_{3}$.

Male : EII + EIII : A - 1s, P - $\mathrm{y}_{1}, \mathrm{D}-\mathrm{y}_{2}-1 \mathrm{~s}\left(\mathrm{z}_{1}\right)-2 \mathrm{~m}$ $(\mathrm{G} 1, \mathrm{G} 3)-11(\mathrm{G} 2$ : ser) / EIV : D - y $-1 \mathrm{~s}(\mathrm{Gm})-1 \mathrm{~m}-$ 11 - 11 (GM : ser).

In males, second and third endopodial articles fused like in females, internal ' $t$ ' setae lack, ' $z$ ' setae reduced to a single seta $\left(\mathrm{z}_{1}\right)$; aesthetasc $\mathrm{y}_{3}$ represents $112 \%$ of 

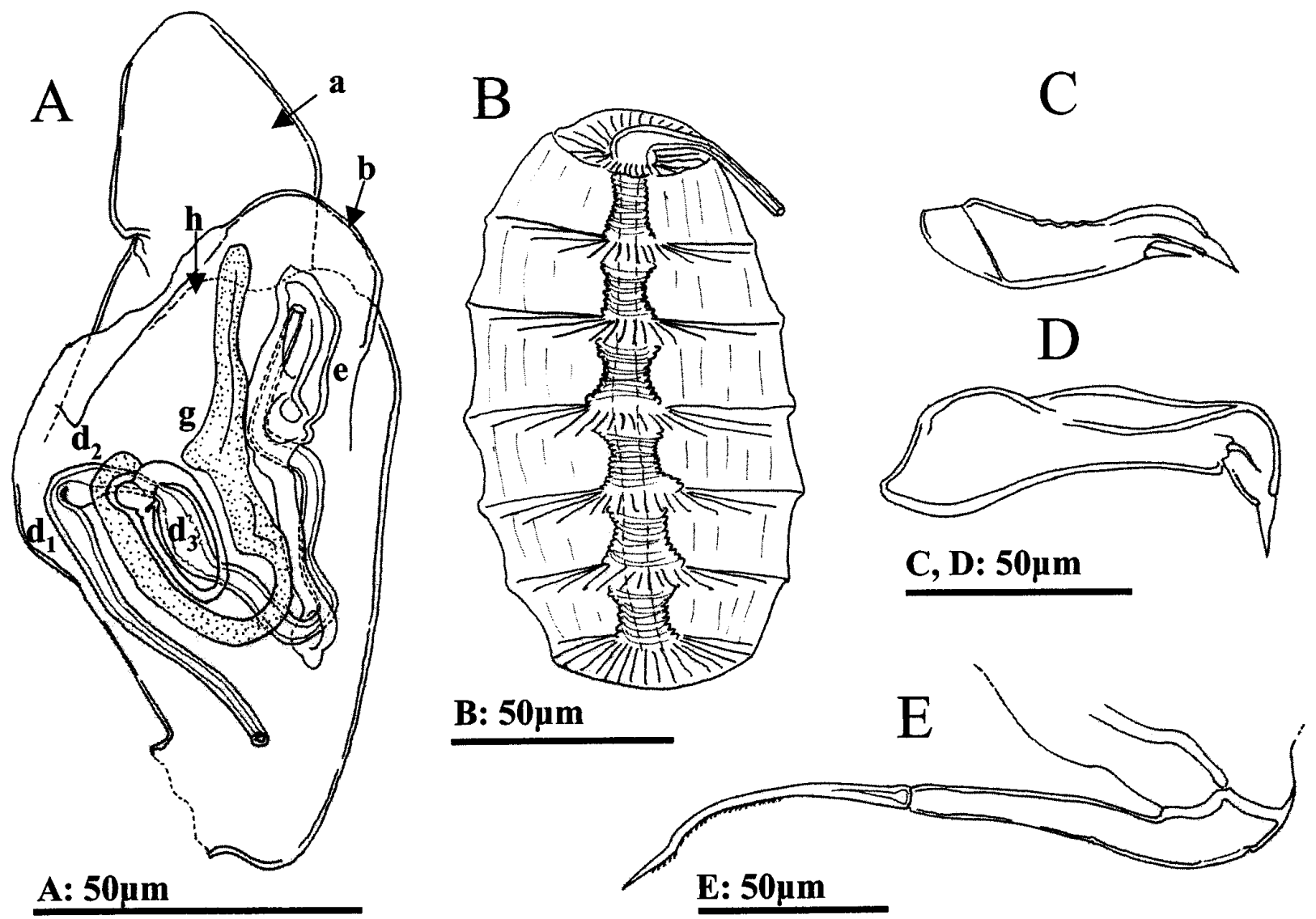

Fig. 6. Marococandona nicolae n. sp. (male) hemipenis (internal view A), zenker organ (B), left clasping organ (C), right clasping organ (D), furca (E).

EI length ; G2 claw is normally developed, it represents $218 \%$ of the first endopodial article ; G1 and G3 claws reduced to medium setae $(89 \%$ and $79 \%$ of EI length respectively); GM claw well developed (196\% of EI length) ; Gm claw shorter than the aesthetasc y3 (only $41 \%$ of EI length). Two setae on EIV, one long associated to $\mathrm{y}_{3}$ and one medium.

Mandibular palp (Figs. 7E). I : In - 1m - 1m (S1 : pu ?) - 1s (S2 : pu) - (1s $\alpha$ ?) / II : Ex - 1s, In - 3m - 1s ( $\beta) /$ III : Ex - 1m - 1s, In - 2s, D - 1s $(\gamma)$ / IV : D - 3s $1 \mathrm{~m}$ ( Gr : ser). Setae $\alpha$ not observed ; $4^{\text {th }}$ article with one claw-like bristles pectinated and fused with the article, which represents $125 \%$ of the $3^{\text {rd }}$ article length. Maxillular palp (Fig. 7D). I : Ex - 4m (pu) / II : D - 2s (pu) - 4m (pu). Claw-like setae on the third mastic process are smooth. Maxilla or first thoracopod (Figs. 6C, 6D, \& 7F). Pr : In - (a ?), 1s (d) / Mastic : D - 10s (pu) / Exo : 2s (?) / E : D - 2s (?). Protopodite 'a' seta not observed; two distal setae on endopodite; only two filaments were observed on the respiratory plate. Male prehensile palps asymmetrical, the left one is regular and cylindrical, the right one is more arched and slightly longer than the left one.

Second thoracopod (Fig. 8B). Pr : no seta / EI : A $1 \mathrm{~m}(\mathrm{e}: \mathrm{pu}) / \mathrm{EII}: \mathrm{A}-1 \mathrm{~s}(\mathrm{f}) / \mathrm{EIII}: \mathrm{A}-1 \mathrm{~s}(\mathrm{~g}) / \mathrm{EIV}: \mathrm{P}$ 11 ( $\mathrm{h}_{2} \mathrm{G}$ :ser). Terminal claw represents $290 \%$ of the EII length. Third thoracopod (Fig. 8A). Pr : Ex 11(d $\left.\mathrm{d}_{1}: \mathrm{pl}\right)$, In - 11(dp:pl) / EI : no seta / EII : no seta / EIII : P - 1s(g:pl) / EIV : D - 1m( $\left.\mathrm{h}_{1}: \mathrm{pl}\right)-2 \mathrm{l}\left(\mathrm{h}_{2}, \mathrm{~h}_{3}: \mathrm{pl}\right)$. All setae plumose. Distal setae represent respectively $191 \%, 466 \%$, and $500 \%$ of the last article length. Furca (Fig. 6E, 8C, \& 8D). Furca strongly reduced with only one distal claw that represents from 138 to $150 \%$ (in females) and from 118 to $130 \%$ (in males) of the anterior margin.

Genital organs (Figs. 6A \& 8C). Female genital 


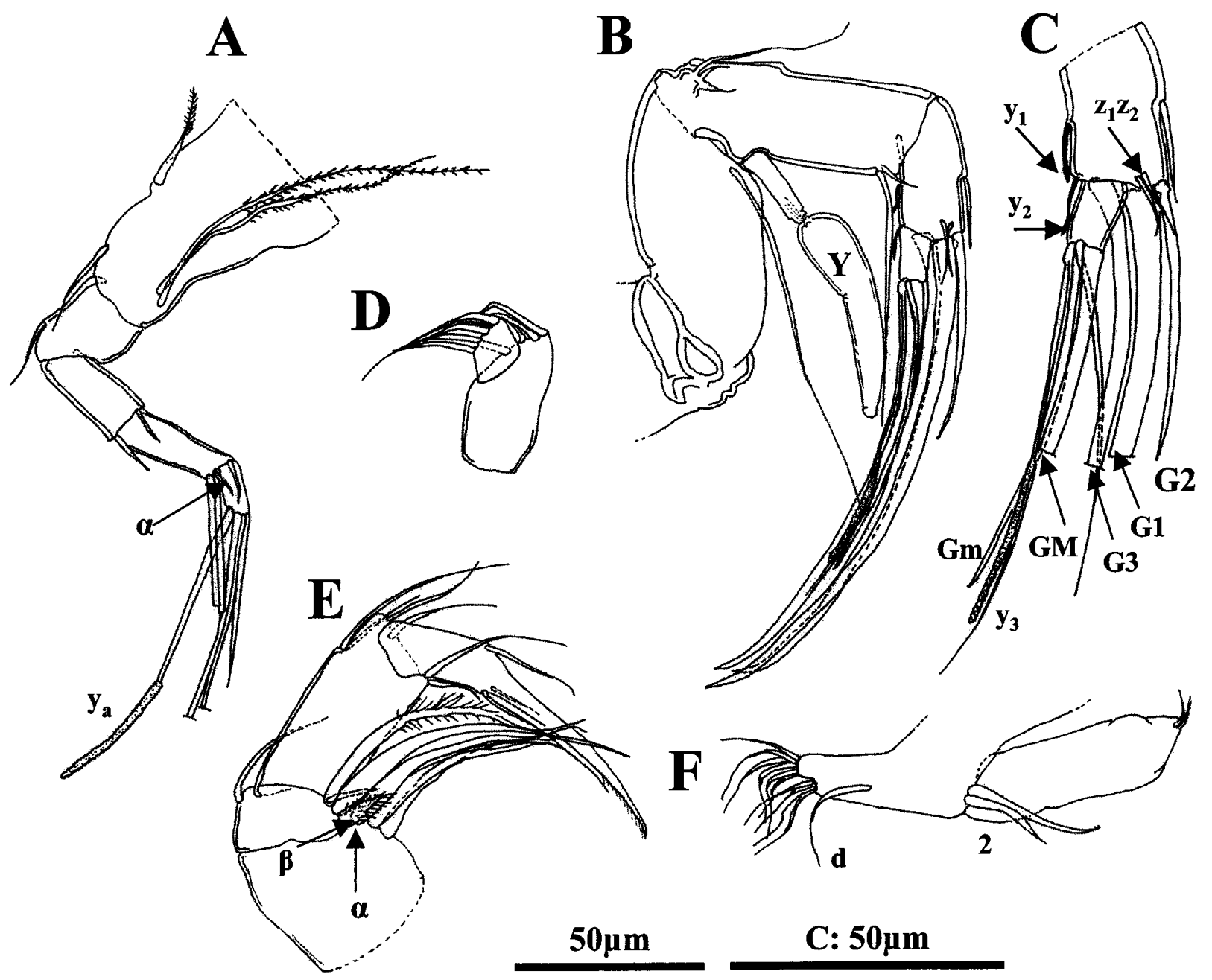

Fig. 7. Marococandona nicolae $\mathrm{n}$. sp. (female) antennula (A), antenna (B with detail of the distal part C), maxillular palp (D), mandibular palp (E), maxilla $(\mathrm{F})$.

lobes flat; the ovocyte represent $15 \%$ of the carapace length. Male hemipenis is well sclerotized with a flat distal 'a' lobe, a 'b' lobe anteriorly rounded, ' $h$ ' lobe poorly developed, double rounded. Labyrinth with only three successive sections $\left(d_{1}, d_{2}, d_{3}\right), d_{3}$ is well developed and surrounded by a sclerotized ovoid structure. Distal part of the copulatory tube is simple, bursa copulatrix ('e') complex, process M well sclerotized, J-shaped, distal end sword-shaped. Zenker organ with $5+2$ chitinous rings (Fig. 6B). Only three lobes were observed for the testes (Fig. 4E).

\section{Ecological requirements of the two species}

During the survey of the stygofauna of the Guelmin region, in 1986-87, seven wells and two springs were sampled over two years (Boutin \& Idbennacer 1989). M. danielopoli $\mathrm{n}$. sp. was sampled in five of these nine stations, four wells (noted P32, P35, P38, and P39 in Boutin \& Idbennacer 1989) and a spring (noted Sa), all located close to a river (the Oued Seyad for the wells and the Oued Assaka for Sa). The species was not sampled in the other spring and the other wells located close the rivers or in the hill slope, at $6 \mathrm{~km}$ of the Oued Seyad (Boutin \& Idbennacer 1989). The species was sampled in deep wells (e.g. 41,5 meters deep for P38), but with shallow piezometric level (between $5.9 \mathrm{~m}$ in well P38 and $10.1 \mathrm{~m}$ in P35). Groundwater in all stations was highly mineralised, with a high electric 


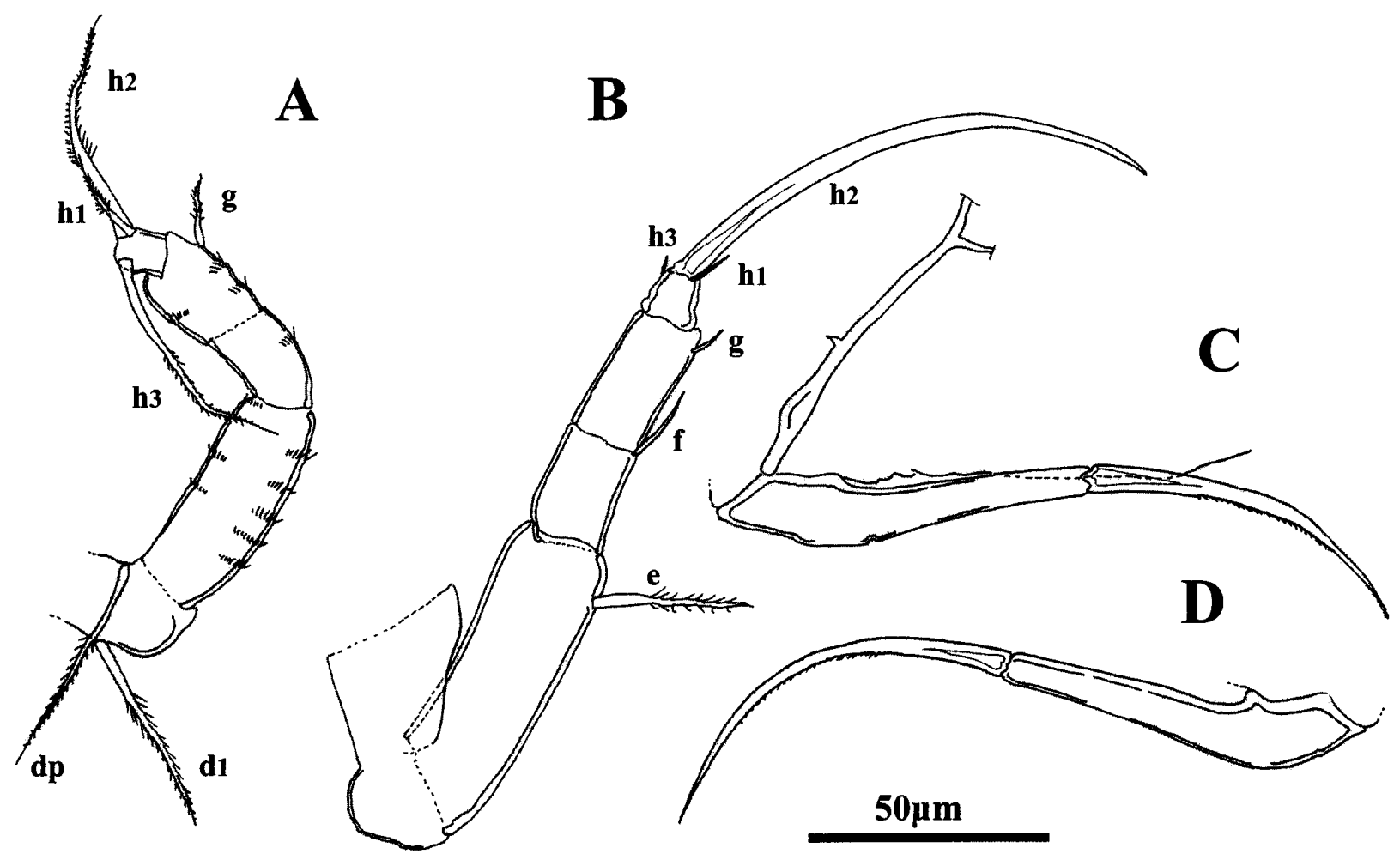

Fig. 8. Marococandona nicolae n. sp. (female) third thoracopod (A), second thoracopod (B), furca and furcal attachment (C \& D).

conductance (from $2092 \mu \mathrm{S}$ for P38 to $4145 \mu \mathrm{S}$ in P32, and $7225 \mu \mathrm{S}$ in the Sa spring) and a strong hardness (around $900 \mathrm{mg} \mathrm{CaCO}_{3} / \mathrm{l}$ in the wells and $1800 \mathrm{mg} \mathrm{Ca}-$ $\mathrm{CO}_{3} / \mathrm{l}$ in $\left.\mathrm{Sa}\right)$. Chloride and sulphate contents were also high because of the geology of the substratum, they reached $426 \mathrm{mg} \mathrm{Cl} / 1$ and $296 \mathrm{mg} \mathrm{SO}_{4} / 1$ in the wells, and $718 \mathrm{mg} \mathrm{Cl} / 1$ and $769 \mathrm{mg} \mathrm{SO}_{4} / \mathrm{l}$ in the spring $\mathrm{Sa}$. Groundwater of the wells was certainly subject to organic pollution, because of the lack of protection around the wells, the shallow depth of the piezometric level, and the high permeability of the soil in this region (Boutin pers. comm.). This is supported by the low-to-medium oxygen contents measured in the wells (from 46 to $63 \%$ of the saturation), while water of unpolluted wells generally reach the saturation. $M$. $d a$ nielopoli $\mathrm{n}$. sp. was collected together with three molluscs (Hadziella sp., Islamia sp., Pseudamnicola sp.) and six crustaceans (Monodella sp., Typhlocirolana sp. Magniezia gardei, Metacrangonyx panusei, Metacrangonyx sp. ; Boutin \& Idbennacer 1989). M. danielopoli $\mathrm{n}$. sp. was sampled with only two other ostracods, Cypridopsis cf. vidua (O.F. Muller) and Heterocypris salina (Brady).
In the region of Agadir, $M$. nicolae n. sp. was sampled in 6 wells on a total of 16 wells sampled four times between fall 1996 and summer 1997 (Boulal et al. 1997). The species occurred in highly mineralised groundwater (electric conductance ranged from $1050 \mu \mathrm{S}$ to $2693 \mu \mathrm{S}$ ), rich in chloride (from 227 to 647 $\mathrm{mg} \mathrm{Cl} / \mathrm{l}$ ) and sulphate (from 85 to $433 \mathrm{mg} \mathrm{SO} / \mathrm{l}$; Boulal et al. 1997). The wells were chosen along a gradient of anthropogenic pollution. M. nicolae $\mathrm{n}$. sp. was present in both unpolluted and polluted sectors: the ammonium contents ranged from 0,01 to $1,86 \mathrm{mg} \mathrm{NH}_{4} / 1$, the nitrate from 0,4 to $59,9 \mathrm{mg} \mathrm{NO} / 1$, and the orthophosphate from 0,08 to $8,95 \mathrm{mg} \mathrm{PO}_{4} / 1$ (Boulal et al. 1997). In the unpolluted wells, M. nicolae n. sp. was found with three hypogean crustaceans (Typhlocirolana sp., Metacrangonyx sp. and Monodella sp.), while only one species (Monodella sp.) occurred together with $M$. nicolae $\mathrm{n}$. sp. in the polluted wells. M. nicolae n. sp. was found with seven other ostracods : Fabaeformiscandona sp., Pseudocandona cf. albicans (Brady), Cypria sp., Cypridopsis cf. vidua (O.F. Muller), Heterocypris salina (Brady), Herpetocypris reptans (Kaufmann), and Darwinula sp. 


\section{Discussion}

\section{Taxonomic remarks}

M. danielopoli n. sp. and M. nicolae n. sp. are grouped in the same genus because of several common characters (see diagnosis of the genus), the most striking are : (1) the chaetotaxy of the third thoracopod, (2) the shape of the male Mxp-clasping organs, and (3) the shape of the hemipenis and its internal structure. They also have some strong morphological differences : (1) antennula with 5 articles, $3^{\text {rd }}$ and $4^{\text {th }}$, and $5^{\text {th }}$ and $6^{\text {th }}$ articles fused, (2) lack of ' $t$ ' setae on the antenna, and (3) strong regression of the furca, without posterior claw and anterior seta in M. nicolae $\mathrm{n}$. sp. These differences may be enough to create two distinct subgenera (Dan Danielopol, pers. comm.), but we prefer to keep Marococandona as a unit until a description of other species of this genus.

In the Candoninae Subfamily and the Tribe Candonopsini, the genus Marococandona is closely related to the genus Candonopsis Vavra. Following the diagnosis of this genus proposed by Danielopol (1980a) and Meisch (2000), seven similar morphological characters can be found in both Candonopsis and Marococandona: (1) the left valve overlaps the right one, (2) the terminal articles of the mandibular palp are conspicuously elongated (a little bit less in Marocodandona than in Candonopsis), (3) the respiratory plate of the maxilla with two or three setae, (4) one short and two long setae on the terminal article of the third thoracopod, (5) furca without the posterior seta, (6) hemipenis flatted and without «d4» branch in the labyrinth and a long distal «a» lobe, and (7) zenker organ with $5+2$ chitinous rings.

Marococandona differs from Candonopsis by the following seven characters : (1) the carapace is not elongated but rectangular, (2) the chaetotaxy of the antennula is reduced in Marococandona, (3) the penultimate articles of the antenna are fused and without male bristles, (4) the lack of seta on the protopodite of the second thoracopod, (5) the third thoracopod with only two setae on the protopodite and no seta on both first and second endopodial articles, (6) the furca is sometimes reduced, consisting of a ramus and a single terminal claw, (7) the male Mxp-clasping organs with a triangular section, a stocky distal part, and a strong asymmetry between left and right organs. These differences support the proposal of the new genus included in the Tribe Candonopsini.

In the genus Candonopsis, two hypogean species $(C$. trichota Schäfer and $C$. thienemanni Schäfer) were described by Schäfer (1945) from Greece, at Armenion near Larisa (see also Danielopol \& Hartmann 1986). These species have two characters similar to Marococandona : (1) a stocky carapace shape (not elongated like in the other Candonopsis) and (2) only two setae on the protopodite of the second thoracopod (not three like in the other Candonopsis), but they differ from Marococandona by three characters : (1) the male Mxp-clasping organs is conical and thin in $C$. thienemanni, (2) the second thoracopod has setae on the first and second endopodial segments in both species, and (3) the hemipenis has a long «b» lobe (as long as the «a» lobe in C. thienemanni). There is thus no overlapping between the two genera.

Marococadona has some affinities with two genera from the West Indies (Broodbakker 1983) Cubacandona Broodbakker and Caribecandona Broodbakker : (1) the rectangular shape of the carapace, (2) the reduction of the number on articles in the antennula (like in Caribecandona), (3) only two setae on the protopodite of the second thoracopod (like in Cubacandona), and (4) the furcal reduction (the posterior claw reduced to a spine in Caribecandona, complete lack of posterior claw in $M$. nicolae). Despite these similarities, Marococandona differs in several characters: the reduced chaetotaxy of the antennula, the antenna (lack of male «Z» seta), and of the third thoracopods, the shape of the male Mxp-clasping organs, the shape of the hemipenis with «a» single a-lobe in Marococandona instead of two «a»-lobes in Caribecandona and Cubacandona.

In the same way, Marococandona has some affinities with the Australian Abcandonopsis Karanovic, a sub-genus of Candonopsis (Karanovic 2004) that include Candonopsis williami Karanovic \& Marmonier, the only species of the sub-genus with a well described male. Seven characters are similar between the two taxa : (1) the terminal segment of the mandibular palp is elongated, (2) the first thoracopod with only one «a» seta, (3) the male clasping organ asymmetric, (4) the basal segment (protopodite) of the second thoracopod without seta, (5) the basal segment of the second thoracopod with only $\mathrm{d} 1$ and dp setae, endopodal ' $e$ ' and ' $f$ ' setae missing, (6) the furca without posterior seta, while posterior claw is well developed or missing, and (7) the hemipenis with a distal, elongated, and triangular a-lobe. Despite these similarities with Abcandonopsis, Marococandona differs in several characters : (1) the shape of the carapace, (2) the antennula with a reduced number of articles, (3) the 3-segmented antenna in males without male sexual bristles, and (4) the shape of the male clasping organs (triangular in section 
and with a stocky distal part).

It is not clear if the similarities listed above are linked to a convergent morphological regression from different ancestors (frequent in hypogean ostracods, see below) or if Marococandona, Cubacandona, Caribecandona and Abcandonopsis represent a phylogenetic unit in the Tribe Candonopsini. Further studies are needed to get a clear picture of this Tribe.

Finally, another African genus Meischcandona Karanovic (2001) has a reduced chaetotaxy of the antennula, of the second and third thoracopods, and of the furca, but this genus differs from Marococandona by the shape of the two distal articles of the mandibular palp and the presence of a posterior seta on the furca. According to this last character, Meischcandona is clearly not related to the Tribe Candonopsini.

\section{Morphological characteristics and life in groundwa-} ters

The two species of Marococandona show numerous morphological regressions (e.g. reduction of number of setae and articles on the antennula, lack of male « $_{2}-$ $\mathrm{t}_{3}$ » bristles on the antenna, fusion of EII +EIII on males antenna, lack of some setae on the second and third thoracopods, reduction of the furcal claws in $M$. nicolae n. sp.). These morphological regressions are very frequent in hypogean animals. As Culver (1985) wrote " the most striking feature of cave organisms (...) is not what they have, but rather what they have lost». The two species show different levels of regression : $M$. danielopoli n. sp. has some primitive characteristics (normally segmented antennula, one ' $t$ ' seta on the antenna, two well developed furcal claws), while the morphology of M. nicolae $\mathrm{n}$. sp. is more regressed, with a 5 segmented antennula, no ' $t$ ' setae on the antenna, and a regressed posterior furcal claw. These morphological regressions correspond to a heterochrony, a stop in the post-embryonic development. For example, the reduction of antennula chaetotaxy in both species and the fusion of the $3^{\text {rd }}-4^{\text {th }}$ and $5^{\text {th }}-6^{\text {th }}$ articles in $M$. nicolae $\mathrm{n}$. sp. make the antennula very similar to those of young larval instar of Pseudocandona albicans (Kovalenko 1983). This reduction is not an exception in the Candoninae, it was already observed in other genera, such as Caribecandona and Danielocandona (Broodbakker 1983), Namibcypris (Martens 1992), Nanocandona (Ekman 1914, Marmonier \& Danielopol 1988). In the same way, the fusion of EII +EIII in males antenna and the lack of transformed «t» bristles, that give a female-like shape to the antenna in adult males, represent a stop at the $8^{\text {th }}$ larval instar (Martens 1987, Meisch 2000). This reduction of the antenna chaetotaxy was previously observed in other hypogean Candoninae, such as Cubacandona (Danielopol 1980a) or the 'zschokkei' group of the genus Pseudocandona (Danielopol 1978b, Marmonier 1988). Finally, the furca of $M$. nicolae n. sp. is also regressed (lack of anterior seta and posterior claw) and looks similar to the furca of a young larval instar of Candoninae (Kovalenko 1983). This furcal regression was already observed in the adult of Danielocandona (Broodbakker 1983), but with a complete fusion between the furcal ramus and the claw in the latter genus.

For groundwater ostracods, eight morphological and reproductive specializations to the life in groundwater were listed (Hartmann 1973, Maddocks 1976, Ginet \& Decou 1977, Danielopol 1978b, 1980b, Marmonier \& Danielopol 1988) : (1) a reduction of the body size, (2) a reduction of body and eyes pigmentation, (3) a reduction of the number of appendages articles and setae, (4) a specialisation of the carapace shape (elongated or stocky), (5) a specialisation of the appendages (elongated walking leg for example), (6) lengthening of the sensory setae (antennal aesthetasc, for example), (7) a reduction of genital apparatus of males (number of testes), (8) an increase in the egg size. Six of these eight morphological specializations were found in the two species of Marococandona : they are small, whiti$\mathrm{sh}$, with a reduce number of setae in most appendages, carapace is stocky (less elongated than in Candonopsis), the aesthetascs are generally long (antennal Y aesthetascs represent more than $150 \%$ of the first endopodial article), testes of $M$. nicolae $\mathrm{n}$. sp. are reduced to three lobes, and the ovocytes are large $(15 \%$ of body length). These morphological characters, together with the habitats where they were collected (wells and springs), support the idea that $M$. danielopoli $\mathrm{n}$. sp. and $M$. nicolae $\mathrm{n}$. sp. are two stygobite organisms.

The two Marococandona species live in water with an extremely high mineralization, $M$. danielopoli $\mathrm{n}$. $\mathrm{sp}$. was found in a spring where the electric conductance reaches $7225 \mu \mathrm{S}$, and $M$. nicolae n. sp. can survive in water that range from 1050 to $2693 \mu \mathrm{S}$. Many ostracod species show a large range of tolerance to water mineralization (e.g. Cypridopsis vidua (O.F. Müller), Delorme 1991), but the ecological requirements of the Candonopsis and of the related genera are poorly known. The three European species (C. kingslei (Brady \& Robertson), C. boui Danielopol, and C. scourfiel$d i$ Brady) and one of the Australian species (C. tenuis Brady) were mostly sampled in freshwater systems with low salinity (Bronshtein 1947, Danielopol 1980a, De Deckker 1982, Meisch 2000). In contrast, the species of the genus Caribecandona were found in a wide 
range of salinity : C. trapezoidea Broodbakker from 31 to $230 \mathrm{mg} / \mathrm{l}, C$. ansa Broodbakker at $140 \mathrm{mg} / \mathrm{l}$, and $C$. auricularia Broodbakker at $420 \mathrm{mg} / \mathrm{l}$ (Broodbakker 1983). The species of the genus Marococandona have a wide tolerance to solute content and seem tolerant to organic pollution (especially M. nicolae n. sp.). Their use as biological indicators for groundwater quality need a preliminary study of their ecophysiological requirements.

\section{Acknowledgements}

We thank Claude Meisch, Ivana Karanovic, Claude Boutin and Dan Danielopol for comments and discussions on previous versions of this article, and Luc Brient and Danièle Jouanneau for technical assistance with the figures.

\section{References}

Bou C. 1974. - Les méthodes de récolte dans les eaux souterraines interstitielles - Ann. Spéléol., 29, 611-619.

Bouçenna A. 1985. - Reconnaissance par sondages de la nappe des calcaires lacustres de la plaine de Seyad-Noun. Arch. hydraul. Agadir, 53, 1-57.

Boulal M., Touyer A. \& Boutin C. 1997. - Qualité de l'eau et faune aquatique des puits près d'Agadir, dans le secteur aval de la plaine du Souss (Maroc). Bull. Soc. Hist. Nat. Toulouse, 133, 59-70.

Bournaud M., Chavannon G. \& Tachet H. 1978. - Structure et fonctionnement du Haut-Rhône français. V Colonisation par les macroinvertébrés de substrats artificiels suspendus en pleine eau ou posés au fond. Verh. Intern. Verein. Limnol., 20, 1485-1493.

Boutin C. \& Boulanouar M. 1983. - Méthodes de capture de la faune stygobie. Expérimentation de différents types de pièges appâtés dans les puits de Marrakech. Bull. Fac. Sc. Marrakech, 2, 521.

Boutin C. \& Idbennacer B. 1989. - Faune stygobie du Sud de l'AntiAtlas marocain : premiers résultats. Sciences Eau, 2, 891-904.

Bronshtein Z.S. 1947. - Fresh-water Ostracoda. Fauna of the USSR. Crustaceans, vol. 2. Academy of Sciences of the USSR Publishers, Moscow, 470p.

Broodbakker N.W. 1983. - The subfamily Candoninae (Crustacea, Ostracoda) in the West Indies. Bijdrag. Dierk., 53, 287-326.

Broodbakker N.W. \& Danielopol D.L. 1982. - The chaetotaxy of Cypridacea (Crustacea, Ostracoda ) limbs : proposals for a descriptive model. Bijdr. Dierk., 52, 103-120.

Chauvin C. 1986. - Le peuplement de trois émergences karstiques en Côte d'Or (France) : premiers résultats. Bull. Sci. Bourg., 39, 89100.

Claret C., Marmonier P., Dole-Olivier M.-J., Creuzé des Châtelliers M., Boulton A.J. \& Castella E. 1999.- A functional classification of interstitial invertebrates : supplementing measures of biodiversity using species traits and habitat affinities. Arch. Hydrobiol., $145,385-403$

Culver D. 1985. - Introduction to the regressive evolution. J. Caves Karst Stud., 47, 70.

Cvetkov L. 1968. - Un filet phréatobiologique. Bull. Inst. Zool. Mus. Acad. Bulgare des Sci., 27, 215-218.

Danielopol D. 1977/78. - Ostracodes hypogés du Sud de la France. 1. Mixtacandona juberthiae n. sp. Int. J. Speleol., 9, 235-249.

Danielopol D. 1978a. - Ostracodes du Sud de la France. 2. Pseudocandona simililampadis n. sp. Int. J. Speleol., 10, 57-71.

Danielopol D.L. 1978b. - Über Herkunft und Morphologie der Süsswasser-hypogäischen Candoninae (Crustacea, Ostracoda). Ös- terreische Akademie des Wissenschaften Mathematica-Naturwissenschaft, 161p.

Danielopol D. 1980a. - Deux espèces hypogées du genre Candonopsis (Ostracoda, Candoninae) du Sud de la France et de Cuba. Vie Milieu, 30, 315-323

Danielopol D. 1980b. - Sur la biologie de quelques ostracodes Candoninae épigés et hypogés d'Europe. Bull. Mus. Nat. Hist. Nat. Paris, 2, 471-506.

Danielopol D. 1981a. - Mixtacandona cottarellii n. sp. un ostracode interstitiel de Sardaigne. Boll. Mus. Civ. St. Nat. Verona, 8, 419 425.

Danielopol D. 1981b. - Distribution of Ostracods in the groundwater of the North Western Coast of Euboa (Greece). Int. J. Speleol., 11, 91-103.

Danielopol D. 1982. - Nouvelles données sur les Candoninae hypogés de Roumanie et Yougoslavie. Bull. Mus. Hist. Nat. Paris, 4 , 369-396.

Danielopol D. L. \& Hartmann G. 1986. - Ostracoda. Pages 265-294 in Stygofauna mundi. A faunistic, distributional and ecological synthesis of the world fauna inhabiting subterranean waters. L. Botosaneanu (ed), E.J. Brill \& Dr W. Backuys, Leiden, The Netherlands.

Danielopol D.L., Rouch R., Bou C. 1999. High amphipoda species richness in the Nert groundwater system (Southern France). Crustaceana, $72: 863-882$

Danielopol D.L., Rouch R. \& Baltanas A. 2002. - Taxonomic diversity of groundwater Harpacticoida (Copepoda, Crustacea) in Southern France. Vie Milieu, 52, 1-15.

De Deckker P. 1982. - Non-marine ostracods from two quaternary profiles at Pulbeena and Mowbray Swamps, Tasmania. Alcheringa, 6, 305-318.

Delorme D.L. 1991. - Ostracoda. Pages 691-722 in Ecology and classification of North American freshwater invertebrates. J.H. Thorp \& A.P. Covich (eds), Academic Press, San Diego, USA.

Dijon R. 1966. - Reconnaissance hydrogéologique et ressources en eau du bassin des Oued Seyad-Ouarg-Noun (Maroc Sud-Occidental). Notes Mém. Serv. Géol. Maroc, 197, 1-197.

Ekman S. 1914. - Beiträge zur Kenntnis der Schwedischen Süsswasser-Ostracoden. Zool. Bird. Uppsala, 3, 1-36.

Facker El Abiari A. 1999. - Rôle des facteurs abiotiques dans la répartition de la faune aquatique souterraine : cas des Crustacés Péracarides stygobies. Ms. C. Thesis, University of Marrakech, Maroc, $208 \mathrm{p}$.

Ginet R. 1982. - Structure et fonctionnement des écosystèmes du Haut-Rhône français. XXIV. Les amphipodes des eaux interstitielles en amont de Lyon - Pol. Arch. Hydrobiol., 29, 231-237.

Ginet R. \& Decou Y. 1977. - Initiation à la biologie et à l'écologie souterraines. Ed Delarge, Paris, $204 \mathrm{p}$.

Griffiths H.I. \& Brancelj A. 1996. - Preliminary list of freshwater Ostracoda (Crustacea) from Slovenia. Ann. Istrian medit. Studies, 9, 201-210.

Gupta L. P. 1984. - Indocandona krishnakanti gen. et sp. nov. (Crustacea : Ostracoda : Candoninae) from subterranean water of Bihar, India. Rec. zool. Surv. India, 81, 291-298.

Hartmann G. 1973. - Zum gegenwaertigen Stand der Erforschung der Ostracoden interstitieller Systeme. Annls Spéléol., 28, $417-$ 426

Ionesco T. 1965. - Considérations bioclimatiques et phyto-écologiques sur les zones arides du Maroc. Cah. Rech. Agr. Rabat, 19, 1-69.

Karanovic I. 1999a. - Two interesting species of Candoninae (Crustacea, Ostracoda) from Montenegro (SE Europe). Bull. Inst. Roy. Sc. Nat. Belgique, 69, 47-56.

Karanovic I. 1999b. - A new genus and two new species of Cando- 
ninae (Crustacea, Ostracoda) from Montenegro (SE Europe). Mem. Biospeol., 26, 47-57.

Karanovic I. 2000. - Pseudocypridopsis petkovskii sp. nov., a stygobiont freshwater ostracod (Crustacea, Ostracoda, Cypridopsinae) from Montenegro (SE Europe). Mitt. Hamb. Zool. Mus. Inst., 97, 59-66.

Karanovic I 2001. - Meischcandona gen. nov. from Africa, with a key to the genera of the subfamily Candoninae (Crustacea, Ostracoda). Bull. Inst. Roy. Sc. Nat. Belg., 71, 93-99.

Karanovic I. 2003.- Towards a revision of Candoninae (Crustacea : Ostracoda) : description of two new genera from Australian groundwaters. Species Diversity, 8, 353-383.

Karanovic I. 2004.- Towards a revision of Candoninae (Crustacea, Ostracoda) : On the genus Candonopsis Vávra, with description of new taxa. Subterranean Biology, 2, 91-108.

Karanovic I. \& Marmonier P. 2002. - On the genus Candonopsis (Crustacea : Ostracoda : Candoninae) in Australia, with a key to the world recent species. Ann. Limnol., 38, 199-240.

Karanovic I. \& Marmonier P. 2003. - Three new genera and nine species of the subfamily Candoninae (Crustacea, Ostracoda, Podocopida) from the Pilbara region (Western Australia). Beaufortia, 53, 1-51.

Karanovic I. \& Pesce L. 2000. - Trapezicandona italica n. sp. from the underground waters of southern Italy. Frag. Entomol., 32, 213-224.

Klie W. 1931. - Zwei neue Arten der Ostracoden Gattung Candona aus unterirdischen Gewässern im südöstlichen Europa. Zool. Anz., 96, 161-168.

Klie W. 1935. - Drei neue Höhlenostracoden aus der Umgebung von Laibach. Zool. Anz., 111, 189-198.

Klie W. 1938. - Ostracoden aus unterirdischen Gewassern in Süditalien. Zool. Anz., 123, 148-155.

Klie W. 1940. - Zur Kenntnis der Ostracodenarten Candona eremita (Vejd.) und C. reducta (Alm). Mitt. Höhl. Karstforsch., 1, 24-29.

Kovalenko, A.L. 1983. - Postembrionalinoe razvitie Candona parallela G.W. Müller (Crustacea, Ostracoda). Izv. Akad. Nauk. Moldavskaia SSR Ser. biol., 1, 33-38.

Maddocks R. 1976. - Pusinellinae are interstitial Bairdidae (Ostracoda). Micropaleontology, 22, 194-214..

Margalef R. 1997. - Rapports historiques et dynamiques entre diversité et biodiversité. Geobios, 21, 107-111.
Marmonier P. 1988. - Biocénoses interstitielles et circulation des eaux dans le sous-écoulement d'un chenal aménagé du Haut Rhône français. Ms. C. Thesis, Univity of Lyon I, France, $161 \& 108$ pp.

Marmonier P. \& Danielopol D.L. 1988. - Découverte de Nanncandona faba Ekman (Ostracoda , Candoninae ) en basse Autriche. Son origine et son adaptation au milieu interstitiel. Vie Milieu, 38, 35-48.

Marmonier P., Vervier P., Gibert J. \& Dole-Olivier M.-J. 1993. - Biodiversity in Ground Waters. Trends Ecol. Evol., 8, 392-395.

Martens K. 1987. - Homology and functional morphology of the sexual dimorphism in the antenna of Sclerocypris Sars, 1924 (Crustacea, Ostracoda, Megalocypridinae). Bijdr. Dierk., 57, 183190.

Martens K. 1992. - On Namibcypris costata n. gen. n. sp. (Crustacea, Ostracoda, Candoninae) from a spring in northern Namibia, with the description of a new tribe and a discussion on the classification of the Podocopina. Stygologia 7, 27-42.

Meisch C. 2000. - Freshwater Ostracoda of Western and Central Europe. Spektrum Akademischer Verlag, Heidelberg. 522 p.

Notenboom J., Plénet S. \& Turquin M.J. 1994. - Groundwater contamination and its impact on groundwater animals and ecosystems. Pages 477-504 in Groundwater Ecology. Gibert J., Danielopol D.L. \& Stanford J.A. (eds), Academic Press, San Diego, USA

Paris P. 1920. - Ostracodes, Biospéologica. Arch. Zool. Exp. Gén., 58, 475-487.

Pospisil P. \& Danielopol D.L. 2000. - Diversity of groundwater dwelling cyclopoida (Crustacea, Copepoda) in a Danube wetland in Austria. Vie Milieu, 50, 137-150.

Rogulj B. \& Danielopol D.L. 1993. - Three new Mixtacandona (Ostracoda) species from Croatia, Austria and France. Vie Millieu, 43, 145-154.

Rouch R. \& Danielopol, D.L. 1997. - Species richness of microcrustacea in subterranean freshwater habitats. Comparative analysis and approximative evaluation. Int. Rev. ges. Hydrobiol., 82, 121 145.

Schäfer H.W. 1945. - Grundwasser-Ostracoden aus Griechenland. Arch. Hydrobiol., 4, 845-866.

Vervier P. 1990. - A study of aquatic community in a karstic system by the use of artificial substrates. Arch. Hydrobiol., 119, 15-33. 